\title{
Law by human intent or evolution? Some remarks on the Austrian school of economics' role in the development of law and economics
}

\author{
Michael Litschka · Kristoffel Grechenig
}

(C) The Author(s) 2009. This article is published with open access at Springerlink.com

\begin{abstract}
In the late nineteenth century, economic analysis of law experienced an outright rejection by the German-speaking legal community. In the second half of the twentieth century, it became a dominant approach in American legal inquiry. We argue that this success was partly due to the insights of Austrian economics which the second wave of law and economics has incorporated. We argue that Austrian legal and economic scholars marked the two cornerstones between which the subsequent discussion oscillated: social planning versus evolution (spontaneous order).
\end{abstract}

Keywords Austrian school of economics - History of law and economics . Spontaneous order · Evolution

\section{JEL Classification $\mathrm{B} 15 \cdot \mathrm{B} 25 \cdot \mathrm{K} 00$}

In 1888, the Austrian Victor Mataja wrote a book on the economic analysis of tort law and contractual liability. Seventy years later, the modern law and economics movement developed without any reference to Mataja and others of his law and economics contemporaries. Indeed, there seems to be no direct link between the

\footnotetext{
M. Litschka

Competence Center for Human Capital Research, Kierlingerstr. 87, 3400 Klosterneuburg, Austria

e-mail: litschka@cchcr.com

K. Grechenig $(\bowtie)$

Department of Law, University of St. Gallen, Bodanstr. 4, 9000 St. Gallen, Switzerland e-mail: Kristoffel.Grechenig@unisg.ch; grechenig@coll.mpg.de

K. Grechenig

Max Planck Institute for Research on Collective Goods, Kurt-Schumacher-Strasse 10,

53113 Bonn, Germany
} 
early works of the late nineteenth century and the start of the modern law and economics movement in the 1960s (Becker, Calabresi, Posner, etc.). However, Mataja and others marked one of two cornerstones of the discussion: social planning, that is, law devised by human intent, where "human intent" refers to the active role of the legislator applying efficiency criteria like the maximization of social welfare. This approach was challenged by the Austrian school of economics (via a critique on neoclassical economic theory) that marked the other cornerstone: spontaneous orders, that is, law developing by (unintended) evolution. Under this approach, the legal system relies mostly on the unintended consequences of the actions of rational individuals. The "Austrian" role in law and economics was precisely to represent these two extremes between which the subsequent discussion oscillated and to contribute some methodological insights which modern law and economics incorporated.

In the late nineteenth century, there was a strong belief in the possibility of social design through laws. However, the assumption that humans could have sufficient information to produce efficient legal norms was increasingly disputed in the following decades. Most importantly, it was Hayek who argued in favor of a spontaneous order that developed through time. This was the starting point of evolutionary legal theories which held that the law evolved towards efficiency and that efficiency was implicitly embedded in the legal system. Even though law and economics scholars such as Posner and Austrians like Hayek did not fully agree on the task of judges within the legal system (Posner 2005), there are remarkable similarities. Both believe that the law, as it evolves, has some built-in correctness. While for Hayek this correctness becomes manifest in a spontaneous order, Posner focused on the efficiency criterion. For legal theory to accept efficiency as a principle, it was essential to convince the legal community that the law, as it was, made economic sense. Much of the early law and economics literature was directed at showing that the law was efficient. It was only after this transformation of legal theory that efficiency has become a widely accepted principle in the law. This allowed law and economics scholars to once more emphasize the design of efficient rules and caused law and economics to shift from positive inquiries to include normative implications again. Not surprisingly, there are discussions in virtually all fields of the law, where legal rules are designed to incentivize people to maximize social welfare. In a sense, today's law and economics has returned to the roots Mataja and others laid down more than a century ago. However, the modern discussion incorporates the Austrian economists' critique on insufficient knowledge when designing legal rules and accounts for an enlarged understanding of subjectivism.

Contrary to earlier work (e.g., Schmidtchen 1991; Krecké 1996), we argue that the Austrian critique has not been rejected, but incorporated in today's law and economics discussion. Schmidtchen argues that law and economics scholars have an "inclination for objectivism" and transform the judge into a "cognitive superman" (p. 335). He emphasizes that only market prices are observable and that those prices provide for little or no information about the subjective values of the market participants (p. 336, 338). Schmidtchen asks how it is possible that a judge decides who is the cheapest cost avoider in a potential accident (p. 338). Likewise, Krecké argues that law and economics models "assume away... the imperfection of human knowledge" and are 
"based on the assumption of omniscience" (p. 20). Since, according to Krecké, "costs are essentially individual and subjective in nature, no external observer can ever grasp the slightest notion of the true value" (p. 24). Due to the fact that a court has to imitate an optimal (hypothetical) contract, that is a contract that the parties would have entered, had there been no transaction costs, the judge has to be an "omniscient external observer" (p. 22). According to Krecké, this runs against the main insights of Austrian economics (AE) which emphasizes the subjectivism of individual preferences and the dispersion of knowledge (p. 24). We argue that law and economics models have incorporated this critique rather than rejected it.

Since this paper focuses on the methodological similarities, it leaves aside a broader political picture along the lines of capitalism versus socialism, laissez-faire versus state intervention, etc. It also leaves aside other philosophical and economic theories that have influenced law and economics, such as, e.g., utilitarianism (Grechenig and Gelter 2008a, b) or welfare economics. Moreover, we do not emphasize the historical connection between $\mathrm{AE}$ and the modern law and economics movement, even though some influence may have been exercised directly or indirectly through the Chicago School (Winkler 2004).

\section{Late nineteenth century law and economics: Mataja's contribution}

Early works in law and economics, understood in today's meaning of an interdisciplinary inquiry, date back at least to the late nineteenth century. Victor Mataja (1857-1934) was one of the most prominent scholars who analyzed the law with economic tools (Winkler 2004). In the monograph "Das Recht des Schadensersatzes vom Standpunkte der Nationalökonomie" ("The law of torts and contractual liability from the point of view of political economy"), published in 1888 (see Mataja 1889) he analyzed the incentive effects of a negligence rule versus strict liability (Englard 1990; Winkler 2004). In the course of elaborating a German Civil Code, this question was of utmost importance. In the case of an act of God, he argued that the costs of damage should not be borne by the owner but by the one who can best prevent the damage. In his analysis, he anticipated the cheapest cost avoider argument later made by Calabresi (1970), Calabresi and Hirschoff (1972), Demsetz (1972). With reference to Böhm-Bawerk, Mataja noted that, due to the decreasing marginal utility of wealth, the costs of damage should be spread over more than one person (Mataja 1889, pp. 27 et seq). Whether distributional effects should be taken into account when designing private law (or whether transfer payments, such as through the tax system, would better fit the task) was later heavily discussed (Kaplow and Shavell 1994, 2000). Mataja was criticized by the legal community for his methodology, not for his results. He was said to have applied a non-legal, and thus, an inadmissible line of arguments (Grechenig and Gelter 2008b). It is relevant to note that Mataja was an important figure at that time. After having finished his doctorate in law at the age of 26 and his "Habilitation" (that is a postdoctoral qualification for becoming a university professor) in "political economy" 1 year later, he was appointed Professor, being Böhm-Bawerk's successor in Innsbruck, and then secretary of trade (Winkler 2004). Mataja would not have been so openly attacked, 
had there not been a widespread consensus against his methodology. What Mataja did was to search for an optimal design of legal rules, when traditional legal scholarship argued that certain rules evolved over time, e.g., out of Roman law (Savigny 1814). In our dichotomy, Mataja's work stands for legislation through intentional social design by humans. Even though, Mataja is sometimes considered Austrian due to his economics publications (Hayek 1992 with reference to Mataja 1884), as a law and economics scholar, he was not advertising a subjective and evolutionary approach.

A second very notable, but similarly disregarded work was Erwin Steinitzer's "Ökonomische Theorie der Aktiengesellschaft" ("Economic Theory of the Public Corporation") of 1908, in which he anticipated several insights of economics, such as the principal-agent problem (Steinitzer 1908, pp. 55 et seq, 64 et seq) and the perspective of the corporation as a nexus of contracts (Steinitzer 1908, pp. 48 et seq; contemporary research regarding 'nexus of contracts' includes, e.g., Jensen and Meckling 1976; Easterbrook and Fischel 1991). By means of four different types of firms, he discussed the misalignment of incentives (or interests, resp.) where ownership and control is separated. Moreover, Steinitzer argued that with an increase in ownership dispersion, shareholders lose power. Because they are not organized, they are subject to an inherent collective action problem (Steinitzer 1908, pp. 64-65).

Other scholars at that time used an economic approach for designing and interpreting the law (Merkel 1895; Mauczka 1904; Unger 1891) or at least recognized economic effects of legal norms (e.g., Steinach 1888). Their main point was that the legal discipline had to look at the law and its effects from a private welfare and social welfare perspective (Winkler 2004). For them, an Austrian approach to lawmaking would have resulted in complete, scholarly apathy when it comes to discussing legal reform. Under this approach, it would not have been the task of lawyers or any other scholars to say whether a legal norm was good or bad, as advocated later by Kelsen (Grechenig and Gelter 2008b).

In spite of this movement, the economic analysis of law in the late nineteenth and early twentieth century remained marginal (Englard 1990; Winkler 2004). For the economic analysis of law to enter the legal discourse a "genuinely legal argument" had to be found first. For this, the Austrian school of economics formed the basis, unintentionally of course, and added a critique to neoclassical law and economics. It contributed to a better understanding of marginalism and subjectivism which are central in modern law and economics inquiry. From a legal point of view, the development has managed to reconcile a fundamental dilemma: first, the fact that we have to evaluate the law, according to some external criteria, when talking about legal reform as well as interpretation (see Gelter and Grechenig 2007 with references to legal realism); and second, the fact that this evaluation is difficult, if not impossible.

\section{Some theoretical and methodological foundations of the Austrian school of economics, according to their relevance for the law and economics paradigm}

Roughly speaking, one can qualify those persons as "Austrian economists" who have taken over and developed further the ideas of founding father Carl Menger. 
According to Leube (1995) we can today distinguish between seven generations of "Austrians", beginning with Menger and his pupils Böhm-Bawerk and Wieser, and later on including names like Mises, Schumpeter, Hayek, Haberler, Machlup, Morgenstern, Kirzner, Rothbard or Lachmann, to name only a few scholars. To see how the Austrian school of economics was connected to law and economics, we start our inquiry in 1871, when Menger's Grundsätze der Volkswirthschaftslehre was published. We will mainly draw from the theories of three major scholars of this school of thought, namely Carl Menger, Ludwig Mises, and Friedrich Hayek, but make references to some more recent authors of AE where appropriate.

In general, the methodology of AE relies on two principles (Vaughn 1994, pp. 3 et seq): First, all phenomena in the social world must be explained via human actions. This principle entails again two major methodological points, namely that economics should be based on "individualism", which can trace back actions and intentions to the single individual, and that all knowledge in economics must come from the subjective interpretation of the environment by the individual ("subjectivism"). Secondly, every action by humans is determined by insufficient knowledge and time. We will have a closer look at what those principles may mean for the development of modern law and economics.

\subsection{Austrian economics and neoclassical economics: introduction into some basic concepts}

There still is no uniform opinion in the economic science on whether AE can really be declared a school of its own that was developed as a critique on NE or it should rather be seen as a variant of NE with some distinct features (e.g., Gloria-Palermo 1999, pp. 11 et seq). While AE purports to have provided some unique insights into the discipline, mainstream economists suggest that $\mathrm{AE}$ has developed using the same criticisms on classical economics that NE claim for themselves. Of course, there are some shared premises of $\mathrm{AE}$ and NE, which has led some authors to think of AE as a branch of the economic mainstream (e.g., Stigler 1941). Firstly their theoretical approach applies simplified logical models abstracting from the complexity of actual events. Within this tenet, predictive power of theories has been a major demand for Neoclassicals, whereas AE stresses the explanatory power of their theories (Crespi 2007, pp. 339 et seq). Secondly, both schools rely on methodological individualism as defined above. Thirdly, both assume rational individual behavior, even though, as will be shown below, NE concentrates on the conscious part of such decisions and AE stresses the meaning of tacit knowledge in such decisions.

The major differences according to Crespi (2007, pp. 341 et seq) are on questions of time and uncertainty (in AE, preferences and knowledge can change before a goal is achieved, in NE, knowledge is, for the most part, perfect). In addition, Austrians do not believe an equilibrium can ever be fully achieved in the economy that could be solved by constrained optimization models and prefer to analyze the market process within evolving institutional frameworks. As regards Law and social institutions, NE poses a stable framework of customary practices and legal rules, while AE sees continuous change and spontaneous orders. As for normative criteria, 
NE looks at different equilibrium outcomes for various initial conditions and is able to form Pareto and Kaldor-Hicks efficiency criteria for policy making. AE see policy changes as influencing individual behavior and preferences which again may change the institutional framework; efficiency criteria in that view would be based on a state that no longer exists after a policy change has been introduced. This may explain the notorious doubts that $\mathrm{AE}$ has shown when it comes to the concept of efficiency being able to be measured by quantitative methods. Similarly, as will be described later on in this paper, intersubjective comparisons of utility are deemed impossible by $\mathrm{AE}$, thereby also lessening the available quantitative possibilities of calculations NE uses in its daily work.

This very rough overview on some basic differences will now be deepened by an analysis of what Menger, Mises and Hayek had to say on some basic methodological questions of economics and their alleged influence on law and economics as it is understood today.

\subsection{Market processes, subjectivism, and marginalism: Carl Menger on the} evolution and design of social institutions and rules

Carl Menger defended a causal-deductive method for scientific analysis. This tenet came out strongly in the famous "debate on methodology" between Menger and Schmoller (see Tieben and Keizer 1997, pp. 3 et seq): The controversial subject was whether the historical-inductive or the causal-deductive method was adequate for economic inquiry, where the first one relies on collecting single data and historical specifications, the second one on constructing general laws by logically deducing from a basic axiom. The strictly logical deduction of concepts led Menger to devise a first "market process theory", explaining the functioning of the market as a process of independent individual actions and decisions. The market process theory generally claims that, when there is an institutional framework of private property and free trade, a spontaneous order will be reached (Ikeda 1994, pp. 24 et seq). This order is brought about by actions and intentions of individuals who act under uncertainty and lack of knowledge. It is not a hypothetical end-state of an equilibrium that is important in this theory (in contrast to NE where equilibria are vital), but the market conditions that provide individuals with the possibility of collecting knowledge and permanently adjust their expectations and actions. One of the first analyses of this kind can be found in Menger (1871, pp. 25 et seq), where he describes the evolution of money through a process of market forces that lead to innovation and efficiency: Goods that are more marketable than others help to find somebody to undertake an exchange with. Logic demands that there are more and more goods produced in this sense, until money arises as the most marketable good. The innovators of this good are imitated until habit makes money a vital institution. All this is done without government influence or laws, only later on the government gives money its status as an instrument protected by law.

We can see two important concepts within the Austrian view already in this early writing, namely the concepts of time and knowledge. When Menger (1871, p. 21) says: "Die Idee der Causalität ist nun aber unzertrennlich von der Idee der Zeit" 
("The idea of causality is strictly tied to the idea of time"), he stresses the importance of causal relationships between preferences and goods. This causality must be analyzed over time and without the concept of an equilibrium. This leads to the later analysis by Hayek of how knowledge in society can be used efficiently. As we only have small parts of all the knowledge we need to conduct economic transactions, only a decentralized way of planning these actions is possible: The price system must provide us with information about subjective valuations of the changing means-ends relations in society (Hayek 1952, p. 113). No central planning or benevolent dictator will ever be able to devise the "right" rules for society, be they legal or ethical or cultural rules. It is interesting to see that Menger obviously believed that the market process will lead to an optimal social order.

The methodological meaning of "subjectivism" is that every explanation of human behavior and interaction should stick to the subjective sense the individual attaches to his or her actions. It is the way we interpret external phenomena that makes up the basis for our decisions. This paradigm has profound implications for social science in general, and law and economics in particular. To find general laws or regularities, so the subjectivist point of view, we have to rely on subjective interpretations. To give an example: The kind of costs an individual includes in his or her calculations is not determined by so called "objective" criteria like the nature of the production process or costs of natural resources, but by his or her own evaluations of a matter, e.g., in terms of opportunity costs. In AE, there are no general or objective laws, but only subjective regularities manifesting themselves in individual decisions. Carl Menger, for example, developed his teachings of value by using the principles mentioned and found that prices are determined by the subjective preferences and mental conditions market participants hold at the time of buying or selling (Horwitz 1994, p. 18). This means that individuals are able to do calculations only via their own cognitive processes which are influenced by experience, expectations, the social environment, etc.

Menger believed that human wants shape economic phenomena without the intermediation of the human will and that values (determined by marginal utilities) occur under complete knowledge (Kirzner 1995, pp. 13 et seq). This implies a logical relationship between consumer preferences and the correct valuation of productive resources, as demanding consumer goods also means evaluating the means of production. Such complete knowledge is, e.g., also assumed by Robbins (1932) and much of modern microeconomics. Menger's subjectivism, according to Kirzner (1995), had more influence on microeconomics than, e.g., Hayek's subjectivism with incomplete knowledge and law and economics seems to draw more from Menger than Hayek. According to Gloria-Palermo (1999, p. 34), however, Austrian subjectivism is more radical than the marginalist embrace of this concept by NE: it is not limited to preferences, but includes expectations, costs, time, and knowledge perception. As such it considers all human choices towards certain ends, not only those limited to utility maximization. In a way, the concept of subjectivism was intensified and enlarged in AE history, beginning with Menger and leading to an extreme form of subjectivism with Lachmann. It is the more moderate understanding of this concept by Menger that has had the biggest influence on the 
methodology of law and economics today. But subjectivism as understood by Austrians also has bearing for the theory of entrepreneurship.

The theory of the entrepreneur has had a long lasting tradition in the Austrian School of Economics. First mentioned by Menger (1871), who stressed the importance of the actions of entrepreneurs for the production process and described these actions as "goods of higher order", more recent theories have been developed, e.g., by Kirzner (1997). He says that traditional theories of the market economy leave out the processes leading to an equilibrium and only describe an equilibrium state already reached. He wonders how so called equilibrium prices or quantities are attained in markets of incomplete knowledge (Kirzner 1988, pp. 14 et seq). It is the "watchful entrepreneur" who seizes opportunities and uses states of disequilibrium to his advantage, which can fill the gap. Because, if expectations of individuals are deceived and their plans can no longer be fulfilled, there is a kind of disequilibrium on a market and a change of plans cannot be explained any more with relative price changes. Such states are much better explained with a concept of bilateral monopolies, as done by Kenneth Arrow in a well-known paper (Arrow 1959). In that paper Arrows showed how decisions of individuals may affect prices, depending on the concentration a specific market is characterised with. On product markets it may well be the sellers who influence prices, on labour markets it could be the buyers (id, p. 47). An analogue argument goes for Kirzner: It is the entrepreneurial individual who can affect prices in states of disequilibrium, and we must rather analyse subjective decisions and expectations than specific equilibria points.

To sum up the argument, there are three elements that make up the so called "entrepreneurial discovery theory of the market process" developed by Kirzner (1997, pp. 69 et seq): (1) The role of the entrepreneur who can change prices and quantities by detecting mistakes made by other market participants; (2) the role of discovery, where the creativity of the entrepreneur can help making decisions within certain framework conditions and there is no need to wait for the conditions to change (as is mostly the case with NE); (3) the role of competition as sole sensible organising principle for market transactions.

As the mutual knowledge of market participants gets more and more complete, there may be a tendency towards equilibrium without ever reaching such a state (as tastes, technology and resources change over time). The elements of learning and surprise enable the entrepreneur to discover new market chances. This is also the main difference to Schumpeter's theory of the entrepreneur: Schumpeter believed that the entrepreneur interrupts a state of equilibrium by creative destruction; Kirzner says the role of the entrepreneur comes into being when a state of disequilibrium exists, and his actions will secure a tendency to equilibrium (Kirzner 1988, p. 129).

All of this has implications for economics and law as scholarly disciplines. While natural sciences provide us with relatively stable laws and replicate situations in experiments, the humanities and social sciences must rather investigate the products of human individual actions and intentions. And even though they are mostly contingent on (subjectively perceived and behaviorally determined) situations, there is a constant "kernel" to be found (Oakley 1997, p. 71). Subjectivism is an 
important methodological tenet of $\mathrm{AE}$, and one that has influenced modern "Rational Choice" theories that can be considered one methodological forerunner to the paradigm of law and economics. Also, the importance Menger attached to subjectivist economics is an indicator of how later on the role of judges is seen in law and economics theories: In demanding a fairly active role of the judge who shall use economic reasoning to assess a legal problem and the consequences of the arising rule, it is via subjectivist evaluations he can achieve that (like, e.g., the evaluation of damages according to marginal cost analysis, i.e., costs the person itself must calculate respective to opportunity costs).

A third theme within Menger's approach to economics with bearing for law and economics is the introduction of a consequent marginalist analysis in microeconomics. While there was a theory of diminishing marginal returns before the Austrians, it was Menger (and at the same time Walras and Jevons) who formulated a consistent marginalist approach (Menger 1871, pp. 90-91). As resources are scarce, we have to choose between different satisfactions of wants which have different values. It was at this point when Menger and the neoclassical economists could solve the classic "paradox of value" that had puzzled the classical economists for so long: How can it be that water with its obvious value for life is so cheap, whereas a diamond with much less "objective" value is so expensive? The answer is that market value and utility are not interdependent; it is the additional unit of water that can be had so easily because of its huge supply that is responsible for its relatively low value on the market. The "marginal utility" of water is low even though the total utility of all available water is surely higher than the total utility of all diamonds on earth. The difference between utility and market value is the consumer rent, which can be explained by the law of diminishing returns. The importance of marginalist analysis for contemporary economics is evident.

We must, however, be cautious not to square Menger's marginalism with the more formalist approaches by Walras and Jevons. As his son Karl Menger pointed out, the non-formal treatment of the marginalist principle by Menger sen. implies an ordinal concept of utility, instead of the cardinality of a continuous utility function. Only comparisons of different levels of utility are allowed, not any form of division, multiplication or derivation (Gloria-Palermo 1999, p. 23). "Menger's homo oeconomicus has little in common with the calculator-maximizer of Walras. It does not refer to an actor with perfect information. The Mengerian homo oeconomicus makes his decisions on the basis of his expectations as his knowledge changes with time and as he realizes the mistakes he may have made in the past" (id, p. 31). However, Menger can be said to have had significant influence with his concept of marginalism on other, more neoclassical authors, and, through this route, also on law and economics.

How has law and economics applied these insights? One obvious application of marginalism and subjectivism was provided by the theory of efficient breach of contract. Roughly stated, a person A sells a good to B but then finds another person $\mathrm{C}$ who is willing to pay more for this good. An efficient allocation of resources would require this good to be transferred to $\mathrm{C}$ (when there are equal wealth restraints), so $\mathrm{A}$ should breach the contract and pay $\mathrm{B}$ damages. Of course, for this efficient breach to occur, the damages $\mathrm{A}$ has to pay B must not be too large, 
otherwise A will not breach the contract (Posner 1998, p. 133; Shavell 2004, pp. 304 et seq). This approach assumes subjective evaluations, depending on one's preferences.

Another example is the protection of property rights to set incentives to produce goods and information. For example, a person will invest in searching for oil if this person is being assigned the property right or the possibility to acquire the oil, once it is found. Abstractly speaking, a person will invest until the marginal benefit equals the marginal cost. If this person owned the full property right it would invest in all socially optimal projects because the full benefits and costs would be internalized. In turn, if a person did not own the full property right, e.g., because it had to disclose the information of having found oil resources, the person will underinvest (Kronman 1978; Posner 1998).

Law and economics scholars have argued that it is the law's task to mimic the market process, when the market fails to allocate goods optimally due to high transaction costs. This has been stated in terms of contract law and economics, where the interpretation of contracts and default rules should correspond to the intentions of the parties, i.e., what parties would have bargained for (Posner 1998), which was also applied to corporations (Easterbrook and Fischel 1991). Of course, this assumes that the legislator or the courts have sufficient information to make this decision, contrary to the Austrian critique (Schmidtchen 1991). However, these rules are used as default rules, leaving it open to the parties to provide for different solutions. In fact, law and economics scholars have taken into account the Austrian critique by arguing in favor of deregulation. One of the first well-known theories includes Manne's book on insider trading (1966) where he discussed the advantages of deregulating insider trading. The underlying assumption was that the parties had more information about their costs and benefits of insider trading; thus they were better suited than the courts and the legislator to decide this issue.

\subsection{Individualism, rational choice and praxeology: Ludwig Mises on rational action}

Methodological individualism tries to ascribe all phenomena of social reality to the actions and intentions of individuals. Society is no discrete entity of its own, but consists of single actions, incentives, and markets. In $\mathrm{AE}$, this stands for a certain kind of skepticism against macroeconomic and econometrical models, because they aggregate single data and suppose a specific structure of the underlying actions (Christiansen 1994, p. 13). If relations on the individual level change, aggregate functions may lead to wrong predictions. Prominent representatives of individualism within the Austrian paradigm were Mises and Hayek. Mises postulates individualism as sole sensible method in the social sciences, because goals of society can never range higher than individual goals. Who should decide over these societal goals? According to Mises (1933, pp. 39 et seq), any decision made in that direction is only an expression of a party dogma. For Hayek, individualism is a fundamental corollary of subjectivism: social phenomena can only be understood via comprehending individual actions directed towards other people and their expected behavior and plans. Oakley (1999, p. 98) calls this an "intersubjective and 
conditioned vision of individualism". Seen like that, individualism and subjectivism are inseparable methodological concepts; but like with the form of subjectivism AE favors and described above, slight differences in understanding of individualism between $\mathrm{AE}$ and NE can be discerned as well.

The individualistic method has had a long tradition in economics for which Austrians were, of course, only one group of contributors. It gave rise to the development of equilibrium economics, where, e.g., institutions can be described as results from rational individual strategies (Sturn 1997, pp. 34 et seq). The Nashequilibrium is one such construct, where a fact is interpreted as resulting from the respective best answers by "players" to the strategies of other "players". Today, game theoretical analyses play a major role in the economic analysis of law (see, e.g., the Annual Conferences of the American and European Law and Economics Associations).

The individualistic method has an underlying concept of rationality, called "instrumental rationality". This kind of rationality is in the center of all rational choice explanations in social science as well as the basis for the "homo oeconomicus" model used in modern microeconomics and law and economics. One of the first scientists to make use of instrumental rationality for an explanation of human behaviour was Max Weber. The concept makes no use of psychological components and only compares the degree of achievement of objectives with the deployment of resources, in order to assess the degree of efficiency. With Hume or Mises, this concept was used so radically that irrational actions were hardly existent, because every action can be depicted as rational in some way. In a more moderate version, used in modern rational choice theories, the consistency of preferences is a criterion for rationality.

Machlup, as another important representative of AE, defended the use of instrumental rationality and the homo oeconomicus in his 1962 paper "The Universal Bogey" (Machlup 1976a) where he cited Mill's definition of that concept as heuristic counterfactual hypothesis (id, pp. 84 et seq). Machlup denied that "Economic Man" should be understood as a pure maximizer of money profits or that wealth should be confined to material goods. Rather, "(h)omo oeconomicus is the metaphoric or figurative expression for a proposition used as a premise in the hypothetico-deductive system of economic theory" (id, p. 93). The economist's main task is then not to explain human action of every sort, but only certain kinds of people's reactions to specified changes in the conditions facing them, given preferences and given information being a useful assumption in that matter (id, pp. 96 et seq) He readily asserts, however (id, p. 97), consistent with the view of most $\mathrm{AE}$, that no quantitative predictions from such a premise can be made.

The many criticisms that have been developed in connection with instrumental rationality would go beyond the scope of this paper. ${ }^{1}$ We should simply be aware of the concept when assessing the connection (via rational choice patterns) between the Austrian methodology and the methodology of law and economics, because the

\footnotetext{
1 In Sen (1987), the ethics and economics view of this topic can be found; in Wright (2003) there is criticism from the side of ethics.
} 
latter discipline, like many parts of social science nowadays, widely relies on rational choice approaches.

Rational choice theories explicate social world phenomena with "rational" actions by individuals. This may have, according to the proponents of such an approach, two distinct advantages: First, psychological ad-hoc assumptions can be omitted for explanations of behavior, secondly, a general theory of human action can be reached by using the same line of argumentation in different social sciences, not only in economics. The transition from individual to institutional levels is analyzed without empirical explanations (Coleman and Fararo 1992, p. x). Individual behavior is depicted as determined by incentives coming from an institutional framework. Within these institutions, the individual "optimizes" in one way or another, e.g., by minimizing costs or maximizing utility. Possible alternatives are compared according to their expected result.

The American economist Gary Becker as a typical representative of „economic imperialism" 2 has often used this approach to analyse a wide field of social phenomena, like the regulation of crime, the economics of the family, or the use of leisure time. To achieve that, he needs the following assumptions (Becker 1976, pp. 5 et seq). The maximisation of a utility or welfare function by individuals; the existence of markets to coordinate human actions; the stability of preferences between individuals and over time.

Since this is a sort of instrumental rationality, alternatives are not assessed directly, e.g., because of certain rules the individual deems appropriate, but by virtue of the consequences the respective allocation of resources will bring (Zundel 1995, p. 27). Assumptions about the specific goals an individual may have are not necessary in this framework, which is why this kind of rationality is strictly formal, not substantial. ${ }^{3}$ More recent versions of rational choice, like the "coherence theory of practical rationality" (described in Nida-Rümelin 1994, pp. 5 et seq) put all available alternatives in a reflexive (each alternative is as good as itself), complete (for each alternative there exists a preference $x>y$ or $y>x$ ) and transitive (if $x>y$ and $y>z$, then $x>z$ ) order. This qualitative order of preferences can be assessed with probability distributions and so be brought into a quantitative order. Actions of choice can be mathematically formulated by this routine. This consequentialist thinking (and ethics, as it is) is of great appeal to law scholars, as it helps them assessing laws through their social effects and not through their intrinsic qualities (Pearson 1997, p. 101). It allows lawyers to analyze alternative regulations and (in most cases) favor one regulation over another.

For law and economics, the reason for assuming a certain kind of rational behavior when designing laws often lies in its practicability. Even though people do not always and in the defined sense act rationally, they are believed to be not too far off this axiom. In market settings, these assumptions are often justified by the idea that irrational players exit the market because they lose to rational players. Due to the complexity of the world, this often seems to be a reasonable simplification for

\footnotetext{
2 Understood as application of economic thinking to the explanation of all human behaviour.

3 See id, pp. 24 et seq. A substantial interpretation of rationality would entail assumptions or even motivations of the individual's goals.
} 
the economic analysis of law. It was also argued to contribute to a more scientific discourse because assumptions are made explicit (Gelter and Grechenig 2007).

How did the Austrians contribute to rational choice theories? The father of AE, Carl Menger, depicted his methodological observations in his Untersuchungen 1883. Therein he developed an understanding of economics which he called "exact" (and theoretical), as opposed to historic-static and practical. He wanted to find the simplest elements of phenomena and looked for laws by which these elements, when combined, result in complex human and social phenomena. The simplest element is that of human "evaluation", and only with this element economic interactions can be explained. Menger (1883, p. 87) showed how these elements can build up an order that follows a causal relationship through a "natural" (he said: "genetic") course. It is not such a long way from Menger's "simplest" element, the element of human evaluation, to the assessment of alternatives according to their expected results, which is in the center of rational choice theory. That decisions and actions by individuals create an unintended order that is causally explicable also through the evaluations done by individuals, is a common viewpoint of Menger, Mises, and Hayek, as well as many modern thinkers in economics, and in the law and economics movement.

Mises set up his theory of "Praxeology" on the basis of Menger's thoughts, but went into a different direction, making it difficult to assess his theory in terms of modern rational choice approaches. Under his approach, economics is built up on the prime axiom of action, defined as: "Action means the employment of means for the attainment of ends" (Mises 1949, p. 13). Mises preferred a Kantian approach to perception in that this and other axioms are valid a priori all historical data. For Mises, evolution brought about the logical structures of thought that are compatible with our physical reality and its causal relationships. The laws of human action reside within man and action is reason applied to purpose. Praxeology (the science of human action) starts with the axiom of action and all implications of economics can be deduced from that axiom (Ebeling 2003, p. 68). The three prerequisites of action are causality, uncertainty, and temporality.

There is no action without the concept of causality: "The category means and ends presupposes the category cause and effect" (Mises 1949, p. 22). The possibility to understand actions by individuals does not come from the observation of a sequence of phenomena but from our understanding of subjectivist interpretations by agents (Cubeddu 1993, p. 13). Again, Mises (1933, p. 31) accepts an instrumental kind of rationality which shall find the right means to attain the goals, whereby the goals are given through the wants and needs of individuals. Mises even goes further: "Human action is necessarily always rational. The term 'rational action' is therefore pleonastic and must be rejected as such." (Mises 1949, p. 18) If an action seems irrational, it is because of a lack of knowledge about the underlying goals the individual follows.

The conception of economics Mises developed is similar to more recent rational choice theories as described above: an aprioristic building with action (decision, choice) as a basis. Aprioristic here means that human beings over time and evolution developed instruments enabling them to understand reality, like, e.g., logical thinking, causality, and teleology. These instruments are there before any 
experience. To give an example: Any experience about money presumes a knowledge of the praxeological category "means of exchange" (Mises 1940, p. 21). If we had not got this knowledge, we would only perceive round metal plates without any specific meaning at all. Or, more detailed: The concept "entrepreneur" is used in Praxeology in a different way than in history (Mises 1940, pp. 61 et seq). In the historical sciences the entrepreneur changes its characteristics in the course of time, they vary according to geography and context. The merchant of the medieval ages is not an entrepreneur in the capitalist sense. In (praxeological) economics instead the entrepreneur is independent from space and time and describes a market phenomenon. If certain premises are fulfilled (like innovative thinking, risk taking, information gathering, etc.), also the medieval merchant can be defined as entrepreneur. This idea comes from deductive deliberations, and not from inductive gathering of data, and it is not the ideal type of a specific class of entrepreneurs or "homo oeconomicus" that economics has to study, but a general a priori theory valid for all human beings interacting on the market.

The methodological subjectivism of Mises "draws attention to the fact that all human actions are 'meaningful', in the sense that the actions are guided by purposes in mind and therefore have a meaning for the actor as defined by him" (Ebeling 2003, p. 125). Prices, e.g., are to be seen in context with the actor's point of view of future possibilities a commodity might provide to him (a satisfaction of needs). Not quantitative ratios count, but anticipation of future market configurations (id, p. 126). This is indeed the biggest difference in the concept of rationality between Neoclassical economists like Becker and the Austrian economist Mises: While NE posits the homo oeconomicus as a human being under complete knowledge of his preferences and ends, and rationality is meant to be the maximization of utility, the rational actor in Mises' theory is able to choose his ends and discover new meansends relationships over time (Oakley 1999, p. 4 et seq). Action is not only an automatic response to given preferences and circumstances in the Misesian framework. "Analytically, rational action was intended by Mises to be a means of giving some core of coherent regularity to the complexity of observed action and its results" (id, p. 51). Goals of individuals, according to Mises, are to be accepted by the scientist, no matter whether they spring from hedonism, utilitarianism or any other philosophy or ethics. It is the respective actions that have to be understood, as ends are not capable of rational justification (id, p. 55). Maybe one can put it that way: With "rational action", Becker stresses the "rational" and Mises the "action".

But Mises' understanding of rationality can also be used as a criticism on mainstream equilibrium economics, as Kirzner (2000, pp. 267 et seq) suggests. Mainstream economics sees the assumption of rational choice as equivalent to assuming universal awareness of all circumstances necessary for choice. "But this assumption... conceals within it also the assumption that the decisions being made (besides-or rather as a result of - their being rational) have all somehow already been modified and co-ordinatively arranged in a mutually sustaining (i.e., an equilibrium) pattern" (id, p. 268). This conception of universal rationality entails the existence of an equilibrium before any decisions are made, while AE (especially the kind of theory endorsed by Mises or Kirzner) squares rationality with purposeful action. 


\subsection{The spontaneous order: Friedrich Hayek on the evolution of rules}

Friedrich Hayek laid down his ideas of a social order most prominently in his book "Law, Legislation, and Liberty" of 1973. Whereas the Austrians described so far (Menger and Mises) can be seen as influencing the paradigm of modern law and economics through their ideas of subjectivism, marginalism, and (partly) rational action, Hayek marks a less obvious cornerstone of law and economics. In fact, it has been argued that Hayek's work discredits the law and economics approach or even demonstrated its theoretical impossibility (Krecké 1996).

In his theories of economics and social science, Hayek (1952) follows the tradition of Locke, Mandeville, Hume, and Smith who accepted the limited knowledge of individuals and relied on abstract principles representing rules that give the greatest possible freedom to the individual. Any departure from these rules (one being, e.g., the market as governing principle for economic actions) must end in arbitrary arrangements limiting freedom. As Hayek mistrusts the ability of individuals to gather enough knowledge to construct a social order by intent (an idea he called "constructivism"), he could indeed be seen as critical of law and economics. For example, Posner believes that a judge can know the (economic) consequences of a rule he sets up, and that he can have the necessary information to conduct for example a marginalist calculation of costs (e.g., Posner 2005). Hayek (1973, pp. 4 et seq) says that the lawyer is ignorant of the order that the rules of just conduct he studies serve, whereas the economist is ignorant of the rules of conduct that serve the order he studies. "We live in a society in which we can successfully orientate ourselves, and in which our actions have good chances of achieving their aims, not only because our fellows are governed by known aims or known connections between means and ends, but because they are also confined by rules whose purposes and origins we often do not know and of whose existence we are often not aware. Men is as much a rule-following animal as a purpose-seeking one" (Hayek 1973, p. 11). Hayek has an evolutionary understanding of rules: they prevail because they made a group successful but were not adopted because of this group knowing their effects (id, p. 17).

The important distinction Hayek makes is the one between "made" order and "grown" order (id, p. 37), as "law-making is necessarily a continuous process in which every step produces hitherto unforeseen consequences for what we can or must do next" (id, p. 65). Judges, lawyers, etc. fit their decisions into a framework of general conceptions, they apply general principles of law and should not question them. They make the system consistent with received and successful rules (id, p. 66). Because of these arguments, legal positivism (in the sense of deriving all law from the will of a law-making authority) is an offspring of constructivism (believing that a purposeful design of an order is possible), and “...it was not through directions by rulers, but through the development of customs on which expectations of the individuals could be based, that general rules of conduct come to be accepted" (id, p. 82). The common law judge, Hayek goes on, has to infer general rules from precedents to apply them to new cases. He must analyze the expectations the relevant parties in a transaction could have reasonably formed under the present order (of just conduct). "The question for the judge here can never be whether the action in fact 
taken was expedient from some higher point of view, or served a particular result desired by authority, but only whether the conduct under dispute conformed to recognized rules." (id, p. 87) Judges and law experts gradually develop by their decisions the system of law which thereby undergoes an evolutionary process. There is interaction of spontaneous growth by customs and deliberate improvements of certain dead-ends such a process may result in (id, p. 100).

The "rule of law" in social systems was also deemed important by Fritz Machlup (1976b). According to him it would be a mistake to believe that freedom implies the absence of any coercion. Coercion may be required to guarantee freedom, e.g., in protecting individuals from restraints put upon them through other groups. This power, he says, must be vested in the government and exercised under the strict rule of law. "This means that all laws apply with equal force to everybody without discrimination and are of such general nature that they can be applied without arbitrary discretion" (id, p. 515). This equality before the law proposition should, however, not be enlarged to encompass any other concepts of equality (of income, of wealth or any other egalitarian notions), says Machlup.

Rule directed, independent, and volitional human actions make up a spontaneous order. An order is a facilitating mediation helping individuals to grasp their situation, guiding their actions under incomplete knowledge, and lessening their uncertainty about the future (Oakley 1999, p. 119). What Hayek does is stressing the importance of economics for understanding abstract, spontaneous orders, but at the same time attributing to law a sole task: to coordinate the actions of individuals according to general rules. He does not want rules to be assessed according to their economic utility, neither positively (why does the rule exist), nor normatively (shall a rule be assessed like that). He calls such a procedure constructivist fallacy and claims it is one of the mistakes utilitarianism makes. Due to an inherent lack of knowledge on part of the decision- and rule-making authority, efficient rules cannot be designed. In a similar vein, Hayek denounced the concept of "social justice" in the form of distributive justice as a void term, as no authority could ever determine the relative incomes of people in a system of free use of knowledge, i.e., a free market system. The pie to be distributed is produced spontaneously, and, as Kirzner (1989) put it, we never know fully what it is that could be distributed. The spontaneous process through which the social pie is created and distributed is a process of discovery, he argues (id, p. 9). Such a process would furthermore speak for a finders-keepers ethics with some implications for law (id, pp. 97 et seq).

The role of spontaneous orders and institutions is indeed central to Hayek's thinking, as it was for Menger's approach. It is interesting though to note an ideological jump from Menger to Hayek as regards the role of institutions (GloriaPalermo 1999, pp. 153 et seq). Hayek defends an evolutionary logic in that institutions and rules are justified by their contribution to the continued existence of a group. This implies a step away from a pure individualist stance which explains institutions through the interaction of individuals and where institutions are effects, not causes. Rather, institutions are seen as efficient if they are spontaneous phenomena-if they exist, it is proof that they are adequate for solving coordination problems between individuals. Menger on the other hand denied that organic phenomena are more efficient than consciously created orders. He accepted 
"pragmatic" orders stemming from human design even though he concentrated on "organic" institutions and individual choices (instead of a principle of group selection) for explaining them. For Menger, the argument can be summed up, institutions are effects of individual interactions, for Hayek they are also causes for the efficiency of groups.

A similar reasoning of Hayek's evolutionary stance applies to the question of equilibrium economics. An equilibrium only makes sense if the foresight of all members in society is correct, and it is only correct if every person's plan is based on expectations of the plans of other people. If all plans are then based on the same set of external facts, and no individual has any intent to change its plans, an equilibrium state is reached (Oakley 1999, pp. 75 et seq). Knowledge of future events is not a prerequisite of an equilibrium, but its defining characteristic, contrary to NE where knowledge is assumed to be perfect. In his famous "The Use of Knowledge in Society", Hayek (1945) gives the most explicit account of how knowledge for economic reasoning in the real world is dispersed among many minds and that if planning is to solve the basic problem of how to acquire this knowledge, then only decentralized planning via the price system (or relative prices) is imaginable. Assuming perfect knowledge does not solve the social problem of change in the economy. Such changes cannot be accounted for in equilibrium patterns.

Today's law and economics analysis has partly incorporated these ideas in its discipline. This may be due partly to the rise of New Institutional Economics, which has used the assumption of systematically incomplete knowledge and borrowed some ideas from AE as well as NE. ${ }^{4}$ For example, a much discussed topic in private law is whether tort law should be governed by strict liability or by a negligence rule. Under a standard of strict liability the tortfeasor was liable whenever he caused an accident, whereas under a negligence rule he was only liable if he did not fulfill the duty of care imposed on him by the law. For unilateral accidents, i.e., where only one person could take care to avoid accidents, strict liability leads to the socially optimal result because all costs were internalized in the tortfeasor's decision. In contrast, the negligence rule was only socially optimal if the standard of care was correctly chosen, otherwise the tortfeasor would choose an inefficient level of care. It was argued that strict liability was favorable due to the fact that the courts (or legislators) did not have the knowledge necessary to determine the optimal level of care accurately (Shavell 2004, p. 181).

\subsection{Austrian economics and law and economics-what is the common core?}

The preceding description of $\mathrm{AE}$ and methodology leads us to the following conclusion: While some of the criticism of AE directed towards NE would also apply to law and economics, and one could be led by this argument to see AE as an opponent to modern law and economics, such a view would be one sided and difficult to defend in the light of the similarity AE has with the modern law and economics paradigm. In this section we begin with the criticism by $\mathrm{AE}$ and then

\footnotetext{
${ }^{4}$ Indeed, it would be interesting, but beyond the scope of this paper, to analyse the relative contributions of $\mathrm{AE}$ and NE to New Institutional Economics and its effects on law and economics.
} 
describe what the two approaches have in common, showing some ways of future developments of a specific "Austrian" version of law and economics.

In economics, the perfect competition theory devised at the end of the nineteenth and beginning of the twentieth century compared the real world with the results the model provided. When these results did not fit, the recognized deviations allowed political interventions. Coase showed that these interventions are costly themselves and recommended judges and the common law should play a vital role in the efficient allocation of property rights (Hülsmann 2004, p. 5). From an Austrian point of view, this turn of the Chicago school was basically right but had the major flaw that the hypothesis remained that subjective values are quantifiable and social computations possible. Carnis (2004, pp. 8 et seq) gives the following example: In the classical model of law and economics (as in, e.g., Becker's and Posner's work) the optimal number of crimes can be calculated via marginal analysis. This, according to $\mathrm{AE}$, has no ethical value but relies on a mechanical cost-benefit analysis to allocate resources. Law is seen as not strictly concerned with individual property rights, as it could as well prohibit such rights or even defend the property of a dictatorship. Also, to minimize social cost, the authority needs information about objective values of goods and services. But, the argument goes, as there is no voluntary exchange if a good is acquired violently (as often happens in criminal transactions), there also is no market to set any price level.

If $\mathrm{AE}$ can be seen as critical towards law and economics, it is via the following methodological arguments: Neoclassical law and economics relies on methodological individualism, the rationality hypothesis, the prerequisite that individuals have property rights, and the demand that decentralized decisions can be made on markets or hypothetical markets (Teijl and Holzhauser 2007, p. 414). AE has doubts as to whether the legislator or a court can have the necessary information to postulate an efficiency solution, a claim that, e.g., Becker or Posner would readily make. By that, AE questions the power of the legislator to device and plan legal rules. Law should rather create space for spontaneous orders which are the result of human action, but not of human design (id, p. 416). Another argument concerns the subjectivity of costs: If costs are subjective, social costs (or welfare) are no useful theoretical concepts as they are immeasurable. Efficiency based judgments on the basis of Pareto optimality are not possible in AE (Mercuro 2007a, b, p. 7). For Austrians, there is no interpersonal comparison of needs or costs that could be used for reaching social efficiency.

Taking theses criticisms together, there are two major problems AE sees in law and economics, at least in its neoclassical formulation: The problem of incomplete knowledge and the problem of social design of rules and institutions. How would an Austrian form of law and economics tackle these problems? Basically, Austrians favor those institutions best suited to promote decentralized decision making. Usually, they claim that markets perform this task better than governments. In contrast to pure (mainstream) NE, social and legal institutions (customs, social norms, legal rules) are important in structuring remedies to the named problems. So the state should specify clear and transparent property rights and promote free markets. It is noteworthy that economic theory, even in its neoclassical form, has gone some way towards this demand (e.g., New Institutional Economics). Legal rules often arise out of customs and social practices, so what judges and legislators should do according to AE is to fill 
gaps in existing rules which have evolved out of social economic activity; a task which Hayek very clearly assigned to the rule-making authority.

The "dynamic disequilibrium process model of capitalism" (Mercuro 2007a, b, p. 8) proffered by $\mathrm{AE}$ also has bearing for another topic of vital interest for law and economics, namely how should externalities be treated? AE would deny a simple excise tax could tackle the issue, but rather demand a better definition of property rights and their enforcement by the courts. Only if people can make their decisions using subjective evaluations and with regard to their own property, can welfare be improved. This implies that standard welfare economics based on general equilibrium and Pareto efficiency is a wrong normative benchmark for social welfare and that the maximization of internalization of external costs should be the only goal of policy in this context, by unambiguously defining property rights (Crespi 2007, pp. 313 et seq).

The acceptance of a priori property rights in one's own body and the right of homesteading goods as prerequisites for an argumentative exchange has been a major argument for Block (2004, pp. 71 et seq, where he draws from ideas of Hoppe) that only a libertarian private property ethic can be a normative starting point for law. Without being able to act and propose and decide now, i.e., without a priori assigned property rights to do so, the analysis of consequences of actions becomes meaningless, lacking the possibility to even formulate any such actions and their consequences. This argument, according to Block, closes the gap between "is" and "ought", and therefore, between AE and law, paving the way for a specific Austrian law and economics. This specific understanding would, according to Block (id, pp. 73 et seq), include inter alia a "first-user-first-owner rule", the denial of the legally binding effect of a promise (as the promise maker commits no aggression against anyone), or the impossibility to separate ownership of property from control over it. While we need not confine the contents of a specific "Austrian" law and economics to these topics (and this paper does not have the goal to define a list of such contents at all), the methodological aspects of AE alone can not be taken as incompatible with modern law and economics.

So, to give another example, even if AE gives no clue as to when intervention in a spontaneous order is demanded, e.g., when outcomes are clearly sub-optimal, it shows ways to hand back decision powers to the relevant parties-those that participate in the dispute. Final offer arbitration and negotiations for settlements in criminal law cases are prominent examples for such a procedure (Teijl and Holzhauser 2007, pp. 425 et seq). Our point here is, that if NE has incorporated some basic tenets of AE (and incomplete knowledge, institutions, and evolutionary thoughts are some examples of this incorporation), law and economics can profit from that as well. In the next section we summarize how law and economics has historically developed exactly in that direction, so that future fertilizations between these approaches seem possible.

\section{The transformation of law and economics}

It was essential for any normative legal theory to argue convincingly that the law as it should be is already the law, properly understood. Only then would a new 
approach be accepted in the legal community and be able to gain importance in the daily work of lawyers. Hayek's theory of legal evolution constituted the basis for such a transformation of legal theory towards an economic approach. It was made explicit in Posner's work on the efficiency of legal rules, where large parts of the law are justified on the basis of economic principles and arguments (Posner 1972). This implies that there is some mechanism that leads the (common) law to evolve towards efficiency. At approximately the same time, Posner and others made this thought explicit, developing theories on how the law tends to produce efficient rules (Rubin 1977; Priest 1997). The main argument was a mechanism through which litigation and relitigation by the parties caused rules to change. Under this theory, parties would be more likely to litigate if the applicable rule was inefficient (Posner 1972). Interestingly, the judges were not assumed to know what the efficient rule was (Priest 1997, p. 65), consistent with Hayek's remarks on insufficient knowledge. Priest argued that, since inefficient rules impose greater costs on the parties, they would be more likely to challenge them. If more inefficient rules are subject to judicial re-examination than efficient rules, inefficient rules are less likely to survive. The law thus evolves towards efficiency. Legal regulation was a hostile intervention into this natural process and thus to be omitted.

This evolutionary approach supported the idea that efficiency was a principle of law and allowed law and economics to enter the regular work of lawyers. Prior to this transformation efficiency was deemed an extra-legal criteria which could be taken into account for policy reasons but not when interpreting the law. The simple normative claims of Mataja and others, without any positive, evolutionary theory, made law and economics look like an alien inquiry to lawyers. The underlying reason that governs much of the civil law tradition is simply that the legislative acts are an expression of the people's decisions and are not to be "reinterpreted" by other criteria (Gelter and Grechenig 2007). Only if it the legal community could be convinced that efficiency is a legal criteria, law and economics could gain importance. To support a normative claim, a positive theory was essential. If efficiency should become a principle of the law, it must be convincingly arguedfor the legal community - that efficiency is already a principle of the law. From this point of view, it was essential for law and economics that social design of legal rules was temporarily discarded in favor of an evolutionary approach. Evolutionary theories of the law based on Hayek's approach made that possible. Once economic analysis became widely accepted, scholars engaged in more normative studies, comparing different legal rules as to their impact on social welfare. In a sense, they returned to the normative scholarship from where law and economics had started in the late $19^{\text {th }}$ century but not without taking into account some of the insights of the Austrian school of economics.

\section{Conclusion}

We have argued that important elements of modern law and economics can be found in the Austrian school of economics without suggesting that there are specific historical links. The Austrians (including non-economists) outlined the dichotomy 
between planning of a legal system, on one side, and evolution or spontaneous orders, on the other side, where Mataja's early contribution was an expression of the possibility of social planning by means of an economic analysis of law. After the transition from Hayek's spontaneous order (and evolutionary approach) to more recent evolutionary theories of law and economics, economic analysis was able to enter the legal disciplines. Clearly, methodology has greatly changed and now includes formal approaches (especially game theory), empirical studies and experimental research. It has incorporated the Austrian critique on some basic neoclassical assumptions and now focuses also on problems of imperfect knowledge, the role of institutions, marginalism and (more radical) subjectivism. This is reflected in a variety of law and economics concepts, including efficient breach of contract and tort law models.

Acknowledgments We would like to thank Christoph Diregger, Martin Gelter and Wolfgang Weigel for helpful comments.

Open Access This article is distributed under the terms of the Creative Commons Attribution Noncommercial License which permits any noncommercial use, distribution, and reproduction in any medium, provided the original author(s) and source are credited.

\section{References}

Arrow, K. (1959). Toward a theory of price adjustment. In M. Abramowitz (Ed.), The allocation of economic resources (pp. 41-51). Stanford: Stanford University Press.

Becker, G. (1976). The economic approach to human behaviour. Chicago: The University of Chicago Press.

Block, W. (2004). Austrian law and economics: The contributions of Adolf Reinach and Murray Rothbard on law, economics, and praxeology. The Quarterly Journal of Austrian Economics, 7(4), 69-85. doi: 10.1007/s12113-004-1004-z.

Calabresi, G. (1970). The costs of accidents: A legal and economic analysis. New Haven: Yale University Press.

Calabresi, G., \& Hirschoff, J. (1972). Toward a test for strict liability in torts. Yale Law Journal, 81, 1033-1092.

Carnis, L. (2004). Pitfalls of the classical school of crime. The Quarterly Journal of Austrian Economics, 7, 7-15.

Christiansen, G. B. (1994). Methodological individualism. In P. Boettke (Ed.), The Elgar companion to Austrian economics (pp. 11-16). Hants: Edward Elgar.

Coleman, J., \& Fararo, T. J. (1992). Rational choice theory. Advocacy and critique. Newbury Park: Sage.

Crespi, G. S. (2007). Extract from "Exploring the complicationist gambit. An Austrian approach to the economic analysis of law". In N. Mercuro (Ed.), Law and economics. Critical concepts in law (pp. 336-383). London: Routledge.

Cubeddu, R. (1993). The philosophy of the Austrian school. London: Routledge.

Demsetz, H. (1972). When does the rule of liability matter? The Journal of Legal Studies, 1, 13.

Easterbrook, F., \& Fischel, D. (1991). The economic structure of corporate law. Cambridge: Harvard University Press.

Ebeling, R. M. (2003). Austrian economics and the political economy of freedom. Cheltenham: Edward Elgar.

Englard, I. (1990). Victor Mataja's liability for damages from an economic viewpoint: A centennial to an ignored economic analysis of tort. International Review of Law and Economics, 10, 173-191.

Gelter, M., \& Grechenig, K. (2007). Juristischer Diskurs und Rechtsökonomie. Journal für Rechtspolitik, 15, 30-41. doi:10.1007/s00730-007-0162-7. 
Gloria-Palermo, S. (1999). The evolution of Austrian economics. From Menger to Lachmann. London: Routledge.

Grechenig, K., \& Gelter, M. (2008a). Divergente Evolution des Rechtsdenkens-Von amerikanischer Rechtsökonomie und deutscher Dogmatik. Rabels Zeitschrift für Ausländisches und Internationales Privatrecht (RabelsZ), 513-561.

Grechenig, K., \& Gelter, M. (2008b). The transatlantic divergence in legal thought: American law and economics vs. German doctrinalism. Hastings International and Comparative Law Review, 31, 295-360.

Hayek, F. A. (1945). The use of knowledge in society. The American Economic Review, 35(4), 519-530.

Hayek, F. A. (1952). Individualismus und wirtschaftliche Ordnung. Erlenbach-Zürich: Eugen Rentsch Verlag.

Hayek, F. A. (1973). Law, legislation, and liberty. A new statement of the liberal principles of justice and political economy. Rules and order (Vol. 1). London: Routledge.

Hayek, F. A. (1992). The collected works of F.A. Hayek: The fortunes of liberalism (Vol. 4). London: Routledge.

Horwitz, S. (1994). Subjectivism. In P. J. Boettke (Ed.), The Elgar companion to Austrian economics (pp. 17-22). Hants: Edward Elgar.

Hülsmann, J. G. (2004). Editorial. The Quarterly Journal of Austrian Economics, 7(4), 3-6. doi: 10.1007/s12113-004-1000-3.

Ikeda, S. (1994). Market process. In P. J. Boettke (Ed.), The Elgar companion to Austrian economics (pp. 23-29). Hants: Edward Elgar.

Jensen, M., \& Meckling, W. (1976). Theory of the firm: Managerial behavior, agency cost and ownership structure. Journal of Financial Economics, 3, 305.

Kaplow, L., \& Shavell, S. (1994). Why the legal system is less efficient than the income tax in redistributing income. The Journal of Legal Studies, 23, 667-681. doi:10.1086/467941.

Kaplow, L., \& Shavell, S. (2000). Should legal rules favor the poor. The Journal of Legal Studies, 29, 821-835. doi:10.1086/468095.

Kirzner, I. M. (1988). Unternehmer und Marktdynamik. München: Philosophia.

Kirzner, I. M. (1989). Discovery, capitalism, and distributive justice. Oxford: Basil Blackwell.

Kirzner, I. M. (1995). The subjectivism of Austrian economics. In G. Meijer (Ed.), New perspectives on Austrian economics (pp. 11-22). London: Routledge.

Kirzner, I. M. (1997). Entrepreneurial discovery and the competitive market process: An Austrian approach. Journal of Economic Literature, 3, 60-85.

Kirzner, I. M. (2000). The driving force of the market. Essays in Austrian economics. London: Routledge.

Krecké, E. (1996). Law and the market order-an Austrian critique of the economic analysis of law. Journal des Economistes et des Etudes Humaines, 3(1), 19-37.

Kronman, A. (1978). Mistake, disclosure, and the law of contracts. The Journal of Legal Studies, 7, 1-34. doi:10.1086/467583.

Leube, K. L. (Ed.). (1995). Die österreichische Schule der Nationalökonomie. Texte. Band 1: von Menger bis Mises. Wien: Manz.

Machlup, F. (1976a). The Universal Bogey. In G. Bitros (Ed.), Selected economic writings of Fritz Machlup (pp. 79-98). New York: New York University Press.

Machlup, F. (1976b). Liberalism and the choice of freedoms. In G. Bitros (Ed.), Selected economic writings of Fritz Machlup (pp. 505-534). New York: New York University Press.

Manne, H. (1966). Insider trading and the stock market. New York: Free Press.

Mataja, V. (1884). Der Unternehmergewinn. Vienna: A. Hölder.

Mataja, V. (1889). Das Schadenersatzrecht im Entwurf eines Bürgerlichen Gesetzbuches für das Deutsche Reich. Archiv für Bürgerliches Recht, 1, 267.

Mauczka, J. (1904). Der Rechtsgrund des Schadenersatzes außerhalb bestehender Schuldverhältnisse. Wien.

Menger, C. (1871). Grundsätze der Volkswirthschaftslehre. Wien: Braumüller (Faksimile Ausgabe Düsseldorf 1990, Wirtschaft und Finanzen GmbH).

Menger, C. (1883). Untersuchungen über die Methode der Sozialwissenschaften und der politischen Ökonomie insbesondere (2nd ed.). Tübingen: J.C.B. Mohr.

Mercuro, N. (Ed.). (2007a). Law and economics. critical concepts in law. London: Routledge.

Mercuro, N. (2007b). Introduction. In N. Mercuro (Ed.), Law and economics. Critical concepts in law (pp. 1-11). London: Routledge. 
Merkel, R. (1895). Die Kollision rechtmäßiger Interessen und die Schadenersatzpflicht bei rechtmäßigen Handlungen. Strassburg.

Mises, L. (1933). Grundprobleme der Nationalökonomie. Untersuchungen über Verfahren, Aufgaben und Inhalt der Wirtschafts- und Gesellschaftslehre. Jena: Gustav Fischer.

Mises, L. (1940). Nationalökonomie. Theorie des Handelns und Wirtschaftens. Editions Union, Genf, Nachdruck Philosophia Verlag 1980, München.

Mises, L. (1949). Human action. A treatise on economics. London: William Hodge.

Nida-Rümelin, J. (1994). Das rational choice-Paradigma: Extensionen und Revisionen. In J. NidaRümelin (Ed.), Praktische Rationalität. Grundlagenprobleme und ethische Anwendungen des rational choice-Paradigmas (pp. 3-29). Berlin: de Gruyter.

Oakley, A. (1997). The foundations of Austrian economics from Menger to Mises. A critico-historical retrospective of subjectivism. Cheltenham: Edward Elgar.

Oakley, A. (1999). The revival of modern Austrian economics. A critical assessment of its subjectivist origins. Cheltenham: Edward Elgar.

Pearson, H. (1997). Origins of law and economics. The economist's new science of law, 1830-1930. Cambridge: Cambridge University Press.

Posner, R. (1972). Economic analysis of law. Boston: Little, Brown.

Posner, R. (1998). Economic analysis of law (5th ed.). New York: Aspen.

Posner, R. (2005). Hayek, law, and cognition. NYU Journal of Law \& Liberty, 1, 147-165.

Priest, G. (1997). The common law process and the selection of efficient rules. The Journal of Legal Studies, 6, 65-82. doi:10.1086/467563.

Robbins, L. (1932). An essay on the nature and significance of economic science, 2nd ed. 1945. London: Macmillan.

Rubin, P. (1977). Why is the common law efficient? The Journal of Legal Studies, 6, 51-63. doi: $10.1086 / 467562$.

Savigny, F. (1814). Vom Beruf unserer Zeit für Gesetzgebung und Rechtswissenschaft. Heidelberg.

Schmidtchen, D. (1991). Jenseits von Maximierung, Gleichgewicht und Effizienz: Neuland für die ökonomische Analyse des Rechts. In C. Ott \& H. B. Schäfer (Eds.), Ökonomische Probleme des Zivilrechts. Berlin: Springer.

Sen, A. (1987). On ethics and economics. Oxford: Basil Blackwell.

Shavell, S. (2004). Foundations of economic analysis of law. Cambridge, Massachusetts: Harvard University Press.

Steinach, E. (1888). Die Grundsätze des heutigen Rechts über den Ersatz von Vermögensschäden, Juristische Blätter, separata, No. 21-30.

Steinitzer, E. (1908). Ökonomische Theorie der Aktiengesellschaft. Leipzig: Duncker \& Humblot.

Stigler, G. (1941). Production and distribution theories. New York: Macmillan.

Sturn, R. (1997). Individualismus und Ökonomik, Modelle, Grenzen, ideengeschichtliche Rückblenden. Metropolis: Marburg.

Teijl, R., \& Holzhauser, R. (2007). The impact of the Austrian school on law and economics. In N. Mercuro (Ed.), Law and economics. Critical concepts in law (pp. 410-428). London: Routledge.

Tieben, B., \& Keizer, W. (1997). Introduction: Austrian economics in debate. In W. Keizer, B. Tieben, \& R. Van Zijb (Eds.), Austrian economics in debate. London: Routledge.

Unger, J. (1891). Handeln auf eigene Gefahr. Jherings Jahrbücher, 30, 363-421.

Vaughn, K. I. (1994). Austrian economics in America. The migration of a tradition. Cambridge: Cambridge University Press.

Winkler, V. (2004). Ökonomische Analyse des Rechts im 19. Jahrhundert: Victor Matajas 'Recht des Schadensersatzes' revisited. Zeitschrift für Neuere Rechtsgeschichte, 26(26), 2-281.

Wright, J. (2003). The ethics of economic rationalism. Sydney: UNSW.

Zundel, S. (1995). Der methodologische Status der Rationalitätsannahme in der Ökonomie. Berlin: Duncker \& Humblot. 